descent, and Prof, Ziegler (Jena), on the present position of this theory in zoology.

On Friday another general meeting of the whole congress was addressed by Prof. Curschmann (Leipzig), on medical science in connection with the shipping industry; by Prof. Nernst (Göttingen), on the use of electrical theories and methods in chemistry ; and by Prof. Reinke (Kiel), on the natural forces at work in organisms.

Several important joint meetings of two or more sections also took place, notably of the biological sections, to discuss the position of biological teaching in schools, the subject being opened by Dr. Ahlborn, of Hamburg. In this discussion Profs. Reinke, Waldeyer, Heincke, R. Hertwig, Chun and others took part, and a committee was formed to consider the matter further. The same sections also were addressed by Prof. R. Hertwig, on the cell theory, Prof. Reinke, on cells without nuclei, and by Prof. Correns, of Tuibingen, on recent discoveries in hybridisation and their bearing on theories of heredity. In connection with the latter paper the author exhibited a remarkable series of specimens illustrating the Mendelian laws of heredity. Joint meetings of the physical and chemical sections also took place to hear papers by Profs. Schilling (Göttingen), Charlier (Lund), Halm (Edinburgh), Simon (Frankfurt), Geitel (Wolfenbiittel), Abegg (Breslau), Hantsch (Würzburg), Wegscheider (Vienna), and many others. The medical and physiological sections had a no less extensive programme, a special feature being a joint meeting in the Concerthaus to receive an address by Prof. Kronecker (Berne) on the innervation of the mammalian heart.

Other meetings of considerable importance were those of the Tuberculosis Committee, under the chairmanship of Prof. Hueppe (Prag). Among the long series of papers read may be mentioned a communication by Dr. Griinbaum, of Liverpool, made on behalf of Prof. Boyce and himself, to the effect that positive evidence had keen obtained by them that bovine tuberculosis could be communicated to the chimpanzee.

Besides the meetings and demonstrations some interesting exhibitions had been organised, amongst others displays of chemical, physical and surgical apparatus, a series of demonstrations of Röntgen-ray apparatus, of the methods of colourphotography, \&c. The museums and other scientific and medical institutions of Hanburg were open throughout the week to members of the congress. As of special interest to naturalists may be named the novel preparations of Dr. Michaelsen, showing by means of artificial spirit-aquariums the modes of life of molluscs, worms and other marine organisms. In the Zoological Garden were exhibited the skeleton and stuffed skin of the gigantic gorilla lately brought from the Cameroons, and bought for the Tring Museum. This specimen, which stands some 6 feet high, is believed to be the finest in Europe. On Friday a special visit was made to the new institution for preventing the introduction of agricultural pests. This is the only institute of the kind in the world excepting that in New York. In it an attempt is made to disinfect all fruit and vegetable produce coming to the port of Hamburg, and thus to check the spread of exotic pests.

Each member was presented with a guide-book and with a large quarto treatise of $600 \mathrm{pp}$. describing and illustrating the natural history of the district, its scientific institutions and resources, similar treatises on the medical and hygienic in. stitutions being in addition presented to the medical members. Each member also received a silver medallion-badge of great artistic distinction specially designed by Herr Illies.

The festivities organised and for the most part provided by the municipality and by residents in Hamburg were on an unusually magnificent scale, far exceeding anything of the kind that had been done before, and probably these evidences of the wonderful prosperity of the great free town will be to the foreign visitor among the most lasting memories of the meeting.

On Sunday, before the congress officially began, the members were invited to see a procession of boats dressed in flowers, which rowed round the inland waters of the Ausser Alster, the entertainment concluding with fireworks on the lake. On Monday the Zoological Garden was illuminated. On Tuesday some 1300 members of the congress were received by the Burgomaster and Senate of Hamburg and entertained at supper in the princely suites of rooms composing the new Rathhaus, while the remainder were invited by the directors of the Hamburg-America line to a similar entertainment on board two of the company's largest vessels. A "Festessen" took place in the Zoological Garden on the following day, at which some
I 500 dined simultaneously. On Thursday a concert was provided, followed by a ball, and on Friday the whole congress was conveyed down the river in five large steamers to Blankenese, returning after dark to see the illuminations which had been arrayed along the whole length of the Elbe. Later in the evening those who were not quite exhausted returned to the Concerthaus to take part in further proceedings of a hilarious character and to listen to speeches of farewell.

On the following day the congress broke up, some joining an excursion to Heligoland, while a larger number went on a two days' expedition to Kiel, Lübeck and other places of interest.

The organisation was brought to the highest possible point of efficiency, and most of the office work throughout the meeting was patiently supplied by volunteers. Provision for the comfort of visitors went even so far as to fill the incoming trains with maps of the town and printed information on all practical matters, and students were waiting on the platforms to find lodgings for and to direct those who might need such help. The number of those who became members for the meeting is said to have exceeded 3000, about 1000 being lady-associates. For the latter, separate entertainments of various kinds were organised on a lavish scale, to take place each day during the scientific business.

It was announced that the meeting for next year will be held at Karlsbad under the presidency of Prof. Chiari, of Prag, with Prof. Selenka and Prof. Stintzing as presidents of the scientific and medical groups, respectively.

\section{PRIZES FOR RESEARCHES IN MEDICAL} SCIENCE.

THE issue of the British Medical Journal for August $3 \mathrm{I}$ is the annual educational number, in which particulars are given as to the medical curriculum, the ways to degrees or other qualifications, and the various medical schools. This number and that of September 7 contain a few particulars as to open scholarships and prizes which are awarded for the purpose of assisting investigations in various subjects connected with medicine, or for researches actually accomplished. The assistance to scientific work given by the Royal Society and the British Medical Association is too well known to make any description of it necessary, but the following statement, abridged from our contemporary, contains mention of many prizes for research not generally known to exist, some of which confer distinction far beyond their monetary value.

The Weber-Parkes Prize is awarded by the Royal College of Physicians every third year for an essay on some subject connected with the etiology, prevention, pathology, or treatment of tuberculosis, especially with reference to pulmonary consumption in man. The prize consists of 150 guineas and a silver medal. A similar medal is also awarded to the essayist who comes next in order of merit. There was no award made in 1900.

The Jacksonian Prize of the Royal College of Surgeons is open to Fellows or members of the College. Its annual value is about $12 l$. For 1901 the subject for the prize is the diagnosis and treatment of bullet wounds of the chest.

The Astley Cooper Prize is a triennial prize of the value of 300 ., which will be next awarded in 1904 for the best essay on the pathology of carcinoma and the distribution and frequency of occurrence of the secondary deposits, corresponding to the various primary growths. The essays must contain an account of original experiments and observations not already published, and be illustrated as far as possible by preparations and drawings.

The William F. Jenks Memorial Prize is given triennially by the College of Physicians of Philadelphia for the best essay on some announced gynæcological or obstetrical subject. It is of the value of about rool. The essays are to be sent to the Chairman of the Prize Committee, from whom full particulars may be obtained. The last award was in January, Igor.

The three following prizes are given for essays on subjects connected with tropical diseases, which must be sent to the editors of the Tournal of Tropical Medicine not later than December 7, I901. An essay on the duration of the latency of malaria after primary infection as proved by tertian or quartan periodicity or demonstration of the parasite in the blood, for the Sivewright Prize; on the spread of plague from rat to rat and from rat to man by the rat-flea, for the Belilios Prize; and on the best method of administration of quinine as a preventive of malarial fever, for the Lady Macgregor Prize.

NO. I 668, VOL. 64] 
The Carmichael Prize is in the award of the President and Council of the Royal College of Surgeons in Ireland. It is of the value of $120 l$., and is given for the best essay dealing with the state of the medical profession in Great Britain and Ireland.

The British Medical Association has instituted two Research Scholarships, awarded annually but capable of being continued for three years, each of the yearly value of $150 l$. These are for the encouragement of research in anatomy physiology, pathology, bacteriology, State Medicine, clinical medicine, and clinical surgery. They are awarded by the Council of the Association on the recommendation of the Scientific Grants Committee.

The Association has also established an Ernest Hart Memorial Scholarship of the annual value of $200 l$., the holder of which is required to devote himself to the study of some subject in the department of State Medicine. Forms of application for these scholarships may be obtained from the General Secretary of the Association.

The Grocers' Company have instituted three Medical Research Scholarships, open to all British subjects, of the annual value of $250 \%$. They are intended as an encouragement to the making of exact researches into the causes and prevention of important diseases.

At Cambridge there are at least two valuable studentships in science, each of the annual value of $200 \%$, and tenable for three years. One is the Balfour Studentship for original research in biology, and especially in animal morphology; and the other the John Lucas Walker Studentship for original research in pathology. At Trinity College the Coutts Trotter Studentship is open in physiology and experimental physics.

In connection with the Jenner Institute of Preventive Medicine a studentship of the value of $150 l$. has been offered. It is open to all British, including Colonial, subjects; it is tenable for one year and is renewable for a second year. It has been instituted for the purpose of research in pathological chemistry.

The Salters' Company Research Fellowship, of the annual value of $\mathrm{IOO}$., is for the promotion of research in pharmacology. It is awarded by the Company on the nomination of the treasurer of St. Thomas's Hospital and a Committee of Selection. It may be held for a term of three years, and the research must be prosecuted in the laboratories of St. Thomas's Hospital.

In connection with University College, Liverpool, are the Alexandra Fellowship in pathology, which was instituted in I899 for a period of five years, and is of the annual value of rool.; and the Colonial Fellowship in pathology and bacteriology, for which there is a preference for members of Colonial universities and medical schools.

The Walker Prize of the Royal College of Surgeons is awarded every five years for the best work in advancing the knowledge of the pathology and therapeutics of cancer. It is of the value of rool. It is open to foreigners as well as British subjects, and it is not intended that essays should be written specially for the competition.

The John Tomes Prize is awarded triennially by the Royal College of Surgeons for original work on dental surgery, pathology, anatomy, physiology, or mechanics. The next award is for the period ending December $31,1902$.

The Cameron Prize, which is of the value of about rool., is given annually by the University of Edinburgh to the member of the medical profession who shall be adjudged to have made the most valuable addition to medical therapeutics during the year preceding.

The Marshall Hall Prize is given every five years by the Royal Medical and Chirurgical Society for physiological and pathological researches relating to the nervous system.

The Alvarenga Prize of the College of Physicians of Philadelphia, of the value of $36 l$., is awarded annually for the best essay on any subject in medicine not already published. The essays, bearing a motto but no name, are to be sent to the secretary on or before May $I$ of each year, and the award is made about July 14 following. A second is given by the Aca. démie de Médicine in Paris, and a third by the Hufeland Society in Berlin, a fourth in Belgium, and a fifth by the Misericordia Hospital of Lisbon.

The Riberi Prize, which is of the value of $800 l$., is offered by the Royal Medical Academy of Turin for original work in anatomy, physiology, pathology, or pharmacology. Research on the history of medicine since the Renaissance may also be sub. mitted. The account of the research must be written in Latin,
French, or Italian, and is to be sent to the secretary of the Academy. The prize is awarded for work done during the previous five years, and the last award was made in 1897 .

The Bressa Prize of the Royal Academy of Science, Turin, is of the value of about $400 \%$, and is given for the most important scientific work produced during a given term of years. The last award was made in 1899 .

The Vallauri Prize, of the value of $1,200 \%$, is in the gift of the Royal Academy of Sciences of Turin, and will be awarded to the scientific investigator, Italian or foreign, who within the period of four years from January I, I 899, to December 3I, I 902 , shall be considered to have published the most noteworthy work on any of the physical sciences, taking that term in its widest sense.

One of the Nobel Prizes is awarded by the Carolinian Institute in Stockholm to the person who has been adjudged to have made the most important discovery in physiology or medicine during the preceding year. Recently two prizes, each of the value of about i, $000 l$. sterling, have been awarded by the Nobel Institute, one to Prof. Finsen, the founder of the Medical Light Institute at Copenhagen, and the other to Prof. Pawlow, of St. Petersburg, for his researches in regard to nutrition.

About thirty open prizes are offered each year by the Académie de Médecine of Paris, of which the most valuable is the François-Joseph Audiffred Prize. This is of the value of $1, \infty 00 l$., and is offered to any person, without distinction of nationality or profession, who in the opinion of the Académie de Médecine is rightly adjudged to have discovered a preventive or cure of tuberculosis. The following are also among the more important offered for the year ending with the end of February, I902; the sum specified in each case does not necessarily go to one candidate, but may be divided. The Academy Prize, awarded annually, worth about $40 l_{\text {., }}$ is this year for a research on the róle of toxins in pathology; the Baillarger Prize, of about $80 l$. (biennial), is for the best work on the treatment of mental diseases and the organisation of asylums; and the Charles Boullard Prize, also biennial, of $50 l$., is for a similar subject. The Barbier Prize, of $80 l$. (biennial), is for the discovery of a cure for such " incurable" maladies as hydrophobia, cancer, epilepsy, typhoid and cholera. The Mathieu Bourceret Prize, of 50 l. (annual), is for work on the circulation of the blood. The Camp. bell Dupierris Prize (biennial), of the value of 96l., is for the best work on anæsthesia or the diseases of the urinary passages. The Chevillon Prize (annual), of $65 l$., is for the best work on the treatment of cancer. The Desportes Prize, of $55 l$. (annual), will be awarded for the best work on practical medical therapeutics. The Herpin (of Metz) Prize (quadrennial), of $50 l$., is offered for a research on the abortive treatment of tetanus. The Theodore Herpin (of Geneva) Prize, of $125 \%$. (annuai), is for a research on epilepsy and nervous diseases. The Laborie Prize, of $2 \mathrm{rol}$. (annual), is given for the greatest advancement in surgical science during the year. The Lefèvre Prize (triennial), of $75 l$., is for a research on melancholia. The Meynot Prize (annual), of ro8\%, is for the best work on ear disease; and the Saintour Prize (biennial), of $166 \%$, for the best work on any subject in medicine.

CHEMISTRY AT THE BRITISH ASSOCIATION.

$\mathrm{IN}$ spite of the fact that a number of papers of general in. terest were contributed to Section $B$ at the Glasgow meeting, the attendance was not so good as at the Bradford meeting last year. After the reading of the presidential address, a paper was read on duty-free alcohol by Dr. W. T. Lawrence, in which it was advocated that the Govern. ment should permit the use of non-methylated alcohol which had not paid duty for scientific purposes. In the course of the ensuing discussion, Dr. T. E. Thorpe drew attention to some of the difficulties with which the Excise Department would have to cope if such a course were permitted, and Prof. A. Michael, of Boston, stated that the United States Government allowed the use of non-methylated duty-free alcohol for scientific purposes and did not seem to meet with administrative difficulties. Dr. A. G. Green presented a comprehensive statistical report on the coal-tar industry, in which the progress made in this industry in Germany during recent years was strongly contrasted with its decadence in this country. The report of the Committee on preparing a new series of wave-length tables of the spectra of the elements was presented. Prof. Adrian Brown contributed a paper on enzymic 